\title{
ANAL YSIS OF CAUSES OF SUBSIDENCE IN THE AREA NEAR UJUNGNEGORO STATION, BATANG REGENCY
}

\section{ANALISIS PENYEBAB TERJADINYA AMBLESAN DI AREA DEKAT STASIUN UJUNGNEGORO, KABUPATEN BATANG}

\author{
Wisyanto ${ }^{1}$ \\ ${ }^{1}$ Pusat Teknologi Reduksi Risiko Bencana - Badan Pengkajian dan Penerapan Teknologi, \\ JI. M. H. Thamrin No. 8, Jakarta 10340 , \\ e-mail:wisyanto@bppt.go.id
}

\begin{abstract}
Changes in human activities from time to time continue to change rapidly. This activity needs the support of a reliable transportation network. Railroad land transportation is the main choice to overcome the impasse of human mobility and distribution of goods. For the smooth and safe use of trains, proper maintenance of the rail network is required. Subsidence of the ground supporting the railroad tracks is a common event that disrupts the functioning of the railroad and becomes part of maintenance, as happened near Ujungnegoro Station. To find out the cause, an analysis of geoelectric data, groundwater basin conditions and local topography has been carried out on it. From the geoelectrical data, it is known that the deposit below the subsidence point contains clay units and the morphology of bedrock where the clay and silt units are deposited is in the form of a basin. In addition, observations of the geological aspects of the surface and its topography show that the soil-gravel pile supporting the railroad track forms a "dam" against the Damar Formation rock units which have a higher elevation than the alluvial deposit units. Finally, from all these conditions it is concluded that the clay content factor and the concentration of water flow are the main factors causing subsidence in the area near Ujungnegoro Station.
\end{abstract}

Keywords: Transportation, subsidence, geoelectric, clay, water-flow

\begin{abstract}
Abstrak
Perubahan aktifitas manusia dari waktu ke waktu terus mengalami perubahan secara pesat. Aktifitas ini perlu dukungan jaringan transportasi yang handal. Wahana transportasi darat kereta api merupakan pilihan utama untuk mengatasi kebuntuan mobilitas manusia dan distribusi barang. Demi kelancaran dan keselamatan dalam pemanfaatan kereta api, dibutuhkan pemeliharaan jaringan rel kereta secara baik. Amblesan tanah penopang rel kereta api merupakan peristiwa umum yang mengganggu fungsi jalannya kereta api dan menjadi bagian dari pemeliharaan, seperti halnya yang terjadi di dekat Stasiun Ujungnegoro. Untuk mengetahui penyebabnya, telah dilakukan analisis data geolistrik, kondisi cekungan airtanah dan topografi lokal terhadap Metoda yang digunakan. Dari data geolistrik diketahui bahwa edapan di bawah titik amblesan terdapat satuan lempung dan morfologi dari bedrock tempat dimana satuan lempung dan lanau diendapkan berbentuk cekungan. Disamping itu, dari pengamatan aspek geologi permukaan dan topografinya memperlihatkan bahwa urugan tanah-kerikil yang menopang jalur rel kereta membentuk "bendung" terhadap satuan batuan Formasi Damar yang mempunyai elevasi lebih tinggi dibanding dengan satuan endapan alluvial. Akhirnya dari semua kondisi tersebut disimpulkan bahwa faktor kandungan lempung dan konsentrasi aliran air merupakan faktor utama penyebab terjadinya amblesan di area dekat Stasiun Ujungnegoro.
\end{abstract}

Kata kunci: Transportasi, amblesan, geolistrik, lempung, aliran-air 


\section{PENDAHULUAN}

\subsection{Latar Belakang}

Sejalan dengan semakin meningkatnya jumlah penduduk, maka semakin meningkat pula ragam kebutuhan manusia. Salah satu jenis kebutuhan yang ada adalah kebutuhan sarana transportasi untuk mobilitas manusia dan pemenuhan barang kebutuhan. Banyak sarana transportasi yang dapat dipakai untuk memfasilitasi pergerakan ini seperti Bus, kapal, kereta api, pesawat terbang dan lain sebagainya. Efektivitas pergerakan orang dan barang sangat bergantung pada jenis transportasi yang ada. Khusus untuk transportasi darat, moda transportasi kereta api manfaatnya dirasa sangat efektif, karena moda ini dapat mengangkut manusia dan barang dalam jumlah yang relatif besar dan tidak terganggu oleh lalu lintas moda transportasi lainnya.

Jaringan rel kereta api di Indonesia sudah dikembangkan sejak jaman Belanda. Jaringan ini dari waktu ke waktu terus bertambah, khususnya dalam masa pembangunan akhir-akhir ini. Keberlangsungan pemanfaatan jaringan kereta api perlu disertai dengan pemeliharaan, baik itu pemeliharaan rangkaian gerbong kereta apinya sendiri maupun pemeliharaan rel kereta apinya. Tingkat keamanan dari pemakaian kereta api ini sangat bergantung pada kondisi rel kereta yang ada. Dengan demikian pemeliharaan rel kereta api menjadi aktivitas rutin/berkala yang dilakukan oleh jawatan kereta api. Berdasarkan perhitungan besar biaya pemeliharaan ruas rel KiaracondongCiroyom pada tahun 2005 adalah sebesar Rp.541.290.650 dengan panjang rel $760 \mathrm{~m}$ atau biaya pemeliharaan per meternya adalah Rp.712.225 (Marisa, 2005). Bisa dibayangkan betapa besarnya biaya yang dibutuhkan bagi pemeliharaan rel kereta api di seluruh

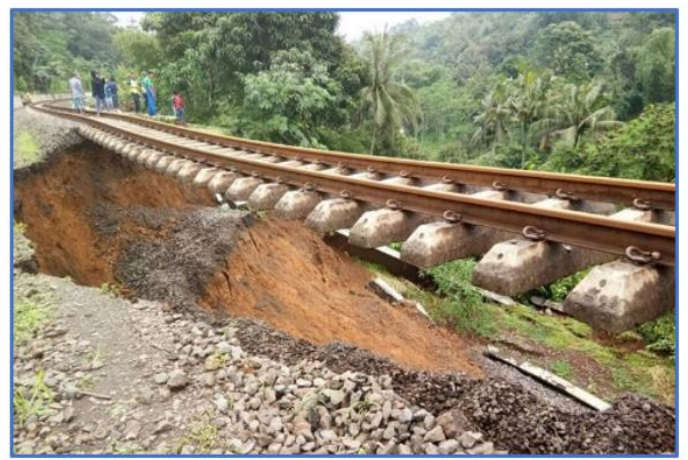

Gambar 1. Longsor di sekitar Rel kereta Bogor-Sukabumi (Sumber: Damanik, 2018)
Indonesia yang panjang jaringan hinnga sampai ribuan kilometer. Hal lain yang berkaitan erat dengan keselamatan pemakaian sarana kereta api adalah antisipasi kerusakan rel dari gangguan bencana alam.

Salah satu ancaman bencana alam yang sering mengganggu dan merusak rel kereta api adalah akibat dari adanya gerakan tanah. Amblesan rel kereta api telah menjadi ancaman terhadap performa jalur kereta dan keselamaatan pengoperasian kereta api (Yang, 2015; Huang, 2015). Banyak peristiwa longsor yang sudah terjadi dan mengganggu keberlangsungan perjalanan kereta api. Longsor yang terjadi di Desa Warung Menteng, Kecamatan Cijeruk, Kabupaten Bogor pada 5 Februari 2018 telah menyebabkan pondasi rel kereta api jurusan Bogor-Sukabumi tergerus. Akibatnya, rel menggantung (Gambar 1) dan perjalanan kereta api dihentikan sementara (Damanik, 2018). Demikian juga longsor yang terjadi pada tanggal 22 November 2012 di Kampung Babakan Sirna, Cilebut Timur, Kabupaten Bogor (Gambar 2) telah mengakibatkan rel kereta tidak berfungsi sama sekali dan ribuan penumpang di Stasiun Cilebut (Toyudho, 2012). Belajar dari kejadian tersebut, maka perlu adanya penyelidikan kondisi tanah di bawah dan disekitar lokasi rel kereta api berada, khususnya pada jalur rel kereta dengan frekuensi lalu lintas yang tinggi. Salah satu perjalanan kereta dengan frekuensi tinggi adalah lintasan rel yang melewati Stasiun Ujungnegoro, Batang. Beberapa kali peristiwa amblesan telah mengganggu rel kereta yang ada di sekitar Stasiun Ujungnegoro. Pada 27 Januari 2019 terjadi lagi banjir yang mengakibatkan amblesnya tanah dibawah rel Stasiun Ujungnegoro (Yunibar, 2019). Melihat seringnya gangguan rel disini, maka penulis mencoba melakukan kajian kondisi bawah permukaan disekitar rel Stasiun Ujungnegoro.

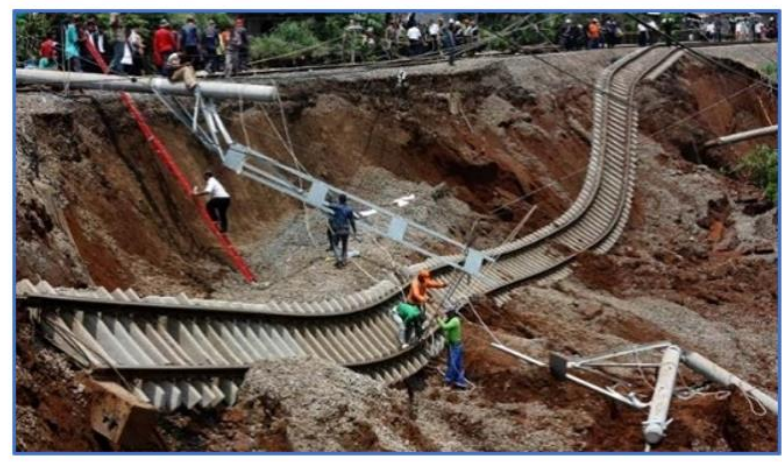

Gambar 2. Longsor di sekitar Rel kereta Cilebut (Sumber: Toyudho, 2012) 


\subsection{Tujuan}

Tujuan dari penelitian ini adalah untuk memahami secara baik kondisi bawah permukaan tanah dan mengetahui penyebab seringnya terjadi amblesan tanah tumpuan lintasan rel di sekitar Stasiun Ujungnegoro.

\section{BAHAN DAN METODA}

\subsection{Bahan}

Penelitian ini menggunakan dua jenis data, yaitu data sekunder dan data primer. Data sekunder berupa data geologi yang diambil dari Peta Geologi Lembar BanjarnegaraPekalongan (Condon, 1996) dan data primer yang didapatkan melalui pengamatan lapangan dan survei bawah permukaan dengan menggunakan alat geolistrik. Adapun hasil survei geolistrik yang sudah dilakukan berupa 3 penampang geolistrik dari 3 lintasan yang masing-masing lintasannya mempunyai panjang $235 \mathrm{~m}$.

\subsection{Metoda}

Penelitian yang terkait dengan kondisi geologis jalur kereta api telah dilakukan dengan berbagai metoda. Seperti penelitian tentang potensi amblesan rel kereta api cepat jalur Beijing-Tianjin dengan menggunakan differential radar interferometry (Linlin, 2010; Yang, 2015; Ding, 2021), analisis numeric finite-element dengan software ABAQUS ( Ye, 2015) dan masih banyak lainnya. Sedang pada penelitian ini, untuk mengetahui penyebab dari seringnya terjadi amblesan tanah penopang rel di Stasiun Ujungnegoro didasarkan pada analisis terhadap hasil pengukuran geolistrik, jenis endapan dan batuan yang sudah ada menurut Peta Geologi Lembar Banjarnegara dan Pekalongan (Condon, 1996), Peta Cekungan Air Tanah Provinsi Jawa Tengah dan Daerah Istimewa Yogyakarta (Setiadi, 2004) dan hasil pengamatan lapangan terhadap kondisi tanah dan topografi lokal. Adapun pengukuran geolistrik, dalam pelaksanaannya menggunakan Ares 48 channel, dengan metoda Wenner dan spasi 5 m. Pengukuran dilakukan sebanyak 3 bentangan dan setiap bentang mempunyai panjang $235 \mathrm{~m}$.

\section{HASIL DAN PEMBAHASAN}

\subsection{Kondisi Geologi Daerah Ujungnegoro}

Dalam membangun jalur kereta api, terdapat beberapa kriteria umum untuk menentukan jalurnya. Ada dua kelompok kriteria utama yang dapat dipakai sebagai dasar penetapan jalur, yaitu kardinal positif dan kardinal negatif. Adapun yang termasuk kardinal negatif, seperti Land Cover/Land Use, Jenis Tanah, Topografi/Slope, dan Sungai. Sedangkan kriteria yang termasuk kedalam kategori kardinal positif yaitu: pusat perekonomian dan Proximity/jarak terhadap jaringan jalan utama (Kuvaini, 2008). Parameter jenis tanah perlu diperhatikan dengan serius, khsususnya terkait dengan kestabilan tanah. Hal lain yang perlu ditekankan adalah masalah yang terkait dengan sesar aktif, gempabumi dan zona seismik sebagai kriteria dalam melakukan pemilihan lokasi track kereta api (Huang, 2013). Parameter ini selain akan mempengaruhi keamanan rel dan keamanan penumpang, juga terkait dengan proses pemeliharaan relnya.

Untuk mengetahui kondisi lapisan tanah/batuan tempat dimana rel kereta api bertumpu, pada awalnya dapat dilihat pada peta geologi yang sudah tersedia. Pada peta geologi dapat diketahui (secara umum) jenis endapan, batuan dan struktur geologinya. Terkait dengan jalur kereta api di sekitar Stasiun Ujungnegoro, peta geologinya dapat dilihat dalam Peta Geologi Lembar Banjarnegara-Pekalongang. Di sini, daerahnya tersusun oleh 4 satuan endapan/satuan batuan seperti terlihat pada peta geologi Gambar 1. Pada peta geologi tersebut terlihat bahwa ada 4 satuan litologi yang ada didaerah ini, yaitu endapan alluvial (Qa) yang terdiri dari kerikil, pasir, lanau dan lempung, endapan sungai dan rawa dengan tebal mencapai 150m. Kipas alluviah (Qf) berupa bahan rombakan gunungapi. Formasi Damar (QTd) yang terdiri dari batulempung tufan, breksi gunungapi, batupasir, tuf dan konglomerat, setempat dijumpai endapan lahar, breksi gunungapi dan tuf bersusunan andesit dan konglomerat bersifat basal. Satuan batuan tertua dibandingkan dengan 3 satuan sebelumnya adalah satuan anggota batupasir dari Formasi Damar (Tpds), terdiri dari batupasir tufan dan konglomerat, sebagian terekat kalsit, bagian bawah berupa konglomerat aneka bahan bersemen karbonat, ke arah atas menjadi batupasir tufan dan konglomerat andesit. Satuan ini secara selaras menindih Formasi Kalibiuk dibawahnya (Condon, 1996). Bila dilihat dalam peta (Gambar 3.) tidak terlihat adanya struktur geologi yang berkembang di sekitar Stasiun Ujungnegoro. Akan tetapi, bila dilihat 
secara keseluruhan dalam peta geologi Lembar Banjarnegara-Pekalongan, ternyata ada banyak struktur geologi yang berkembang berupa sesar-sesar naik dan turun dengan arah umum strukturnya BaratLaut-Tenggara, yaitu dibagian selatan Kabupaten Batang sampai masuk Daerah Banjarnegara. Meskipun demikian, tidak menutup kemungkinan bahwa di daerah telitian yang menurut laporan sering mengalami gerakan tanah terdapat struktur geologi tetapi tidak terpetakan dalam Peta Lembar Banjarnegara-Pekalongan yang berskala cukup kecil (1:100.000). Untuk itu penyelidikan detil bawah permukaan perlu dilakukan.

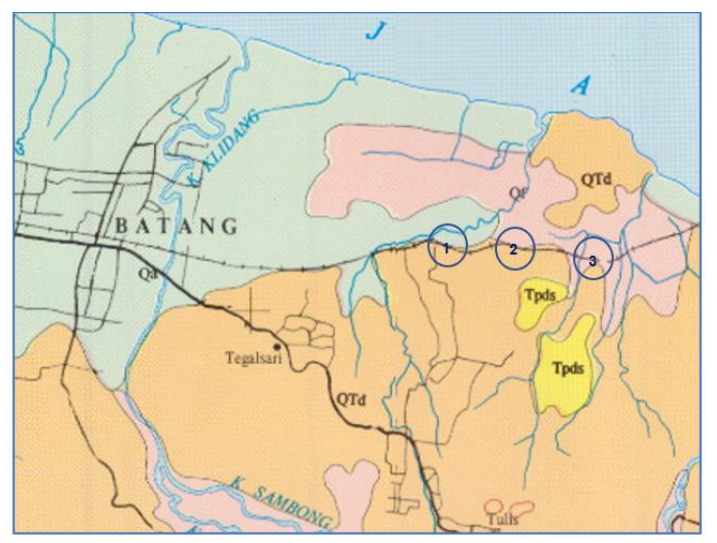

Gambar 3. Peta Geologi Daerah Sekitar Stasiun Ujungnegoro dan titik survei geolistrik, 48 merupakan lintasan 1, demikian juga untuk 2 dan 3 (Sumber Peta: Condon, 1996)

\subsection{ANALISI KONDISI PERMUKAAN}

BAWAH

Untuk mengetahui kondisi bawah permukaan diperlukan survei geofisika, dalam hal ini geolistrik. Metode ini dirasakan cukup jika hanya untuk mengetahui struktur / kondisi bawah permukaan yang dangkal. Pada penelitian ini, digunakan Ares 48 channel, dengan metoda Wenner dan spasi 5 $\mathrm{m}$. Dengan demikian panjang dari setiap bentangan adalah $235 \mathrm{~m}$ dan hasilnya dapat mencapai kedalaman $40 \mathrm{~m}$. Pada penelitian ini dilakukan 3 titik/bentangan survei sejajar dengan rel kereta api (Gambar 3. ). Interval antar bentangan $\pm 750 \mathrm{~m}$, dimana titik tengah dari garis survei adalah Stasiun Ujungnegara yang pernah mengalami gangguan penurunan tanah pada landasan rel kereta apinya.

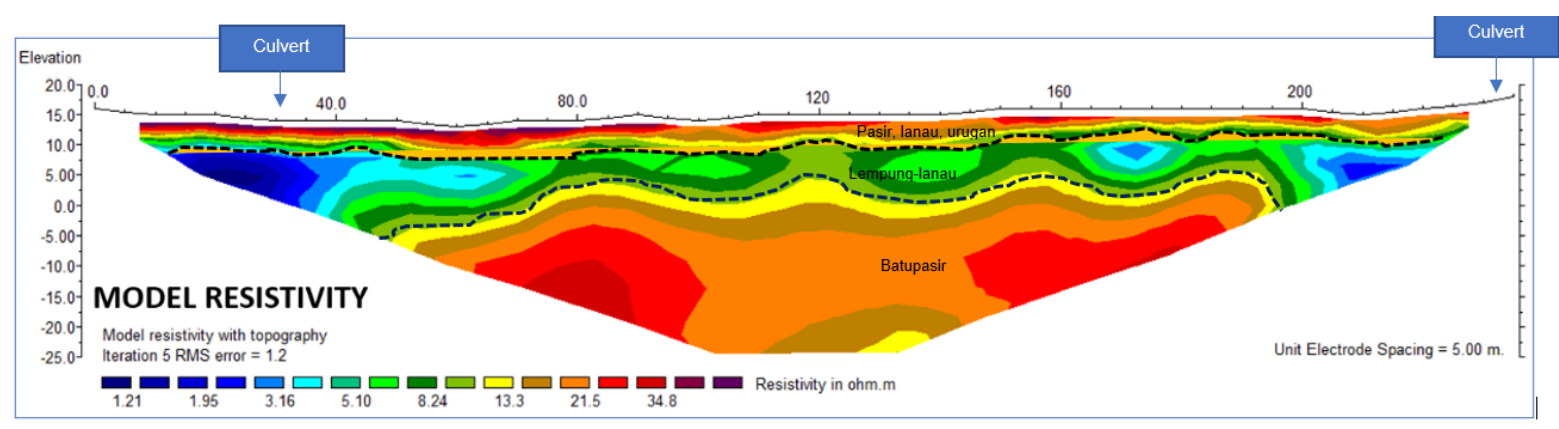

Gambar 4. Penampang geolistrik 1 terletak di sebelah barat Stasiun Ujungnegoro. Pada ujung barat dan ujung timur terdapat selokan / culvert yang memotong rel kereta.

Pada pengukuran geolistrik Lintasan 1 (Gambar 4.), terlihat bahwa stratifikasi endapannya cukup jelas dan melampar luas secara horizontal. Pada bagian teratas berupa pasir, lanau dan urugan yang merupakan bagian dari satuan alluvial. Dibawahnya berupa satuan endapan lempung-lanau dan yang terbawah adalah batupasir. Satuan endapan teratas mempunyai ketebalan $\pm 4 \mathrm{~m}$, sedang endapan dibawahnya mempunyai ketebalan $7 \mathrm{~m}$ sampai lebih dari $15 \mathrm{~m}$. endapan dengan ketebalan $>15 \mathrm{~m}$ terletak di bagian ujung barat dan timur dari lintasan / penampang dan berupa endapan dengan komposisi dominannya adalah lempung. Tepat pada keduanya terdapat saluran / culvert yang melintang rel kereta api. Seperti telah disinggung diatas, bahwa lapisan terbawah berupa batupasir yang besar kemungkinan merupakan bagian dari Formasi Damar. Satuan ini mempunyai ketebalan $>25 \mathrm{~m}$ dan berdasarkan interpretasi penampang yang ada, terindikasi bagian ini mulai terlihat 
mengandung air tanah pada kedalaman 40 m.

Hal yang menarik disini adalah penampakan yang hampir mempunyai pola yang sama disekitar culvert baik yang ada disisi barat maupun timur. Dibawah culvert, nilai resistivitas endapannya sangat rendah. $\mathrm{Hal}$ ini besar kemungkinan karena pengaruh genangan air dari saluran ini (ada yang merembas keluar culvert). Disamping itu, endapan disini sama-sama endapan yang memiliki ketebalan lebih dibandingkan dengan sampingnya. Jadi pemilihan letak culvert juga mungkin didasarkan pada morfologi awal yang relatif rendah pada bagian berkomposisi lempung yang lebih mudah tererosi dibanding bagian lainnya.

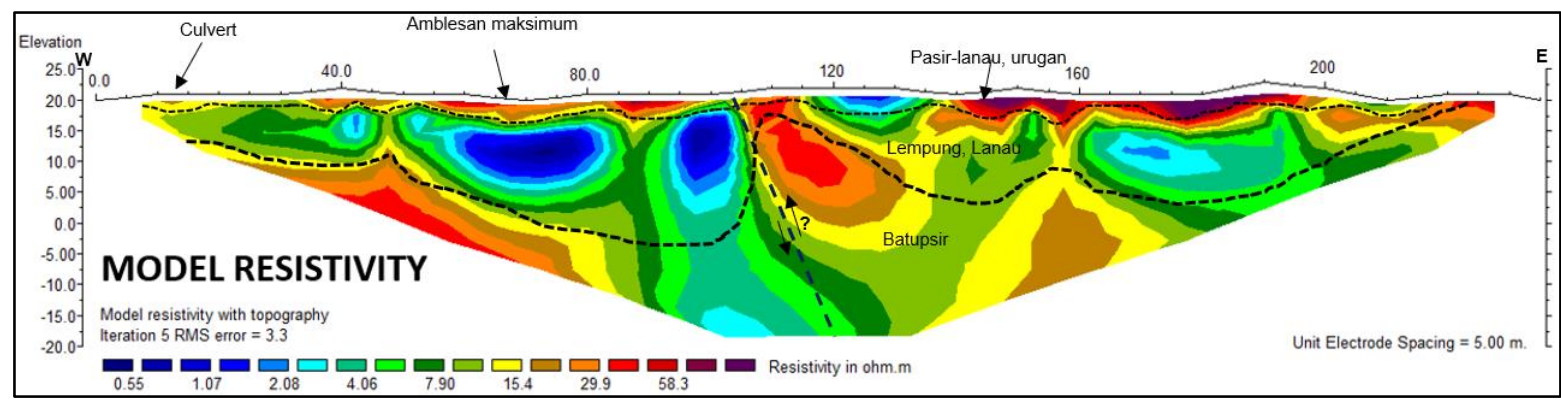

Gambar 5. Penampang geolistrik 2 terletak di dekat Stasiun Ujungnegoro, dimana culvert berada di ujung barat Penampang 2 dan $\pm 50 \mathrm{~m}$ disebelah timurnya terdapat amblesan rel kereta.

Pada penampang geolistrik 2 (Gambar 5 .) hampir sama dengan penampang 1 , dimana secara vertikal kondisi bawah permukaannya disusun oleh 3 satuan batuan, teratas berupa pasir, lanau dan urugan, lapisan tengah berupa endapan lempung-lanau dan lapisan terbawah adalah batupasir. Hal yang membedakan penampang 1 dan 2 adalah bentuk batasnya, baik batas antara lapisan teratas dengan lapisan tengah, maupun lapisan tengah dengan lapisan terbawah. Batasnya merupakan permukaan yang relatif kasar / tidak rata, terlebih pada batas satuan tengah dengan satuan terbawah. Batas satuan terbawah dengan yang tengah pada bagian tengah penampang mempunyai cekungan yang cukup menonjol. Pada penampang geolistrik 2, ditarik garis sesar dimana bagian barat turun dan timurnya naik. Akan tetapi sebenarnya penulis lebih cenderung menginterpretasikannya sebagai akibat dari proses erosi pada permukaan lapisan terbawah (batupasir) sebelum ada proses pengendapan satuan lempung-lanau diatasnya, dimana lapisan lempung-lanau ini merupakan satuan kipas alluvial (Qf) pada peta geologi yang diterbitkan oleh Pusat Survei Geologi.

Culvert terdapat di sisi ujung sebelah barat dari penampang 2. Kurang lebih $50 \mathrm{~m}$ kearah timurnya, tanah dibawah rel (sisi utara) beberapa kali mengalami penurunan. Rel sisi utara lebih parah mengalami amblesan dibandingkan dengan sisi selatannya. Hal ini pasti mempunyai fenomena tersendiri yang menyebabkannya dan besar kemungkinan karena pengaruh horizontal. Pada lapisan yang mengalami amblesan maksimum, khususnya pada landasan rel sisi utara, tanah dibawahnya mempunyai nilai resistivitas yang rendah, yaitu sampai < $1 \Omega \mathrm{m}$. Satuan ini diinterpretasikan sebagai satuan lempung. Pada lapisan diatasnya terdapat endapan dengan nilai resistivitas sampai $30 \Omega \mathrm{m}$, besar kemungkinan ini merupakan material urugan. Dimana secara lebih detil terlihat bahwa material ini semakin tebal dibanding dengan sisi barat timurnya tepat diatas dari lengkung kebawah satuan lempung. Penebalan satuan ini mungkin berkaitan erat dengan proses pengurugan yang telah dilakukan berulangkali untuk mengatasi amblesan rel yang sudah pernah terjadi.

Morfologi lapisan batupasir secara relatif berkecenderungan menjadi tinggian kearah barat dan timur pada Penampang 2. Hal ini bila dikaitkan dengan kenampakan lapang nampak bahwa lintasan geolistrik 2 yang terdapat pada area lahan warna abu-abu / sawah terdapat dalam lekuk yang diapit oleh satuan batuan Formasi Damar yang terlihat berupa tutupan hijau / tutupan tanaman rapat pada Gambar 7. Rona (tone) citra pada Gambar 7 ini selaras dengan kenyataan lapangan yang mengekspresikan perbedaan ketinggian dan perbedaan formasi batuan, dimana area abu-abu berupa endapan alluvial dan mempunyai topografi lebih rendah dibandingkan dengan yang berwarna 
hijau yang berupa batupasir. Interpolasi berdasarkan warna ini dapat memberi gambaran lebih detil dibandingkan dengan batas satuan batuan pada peta geologi yang ada.

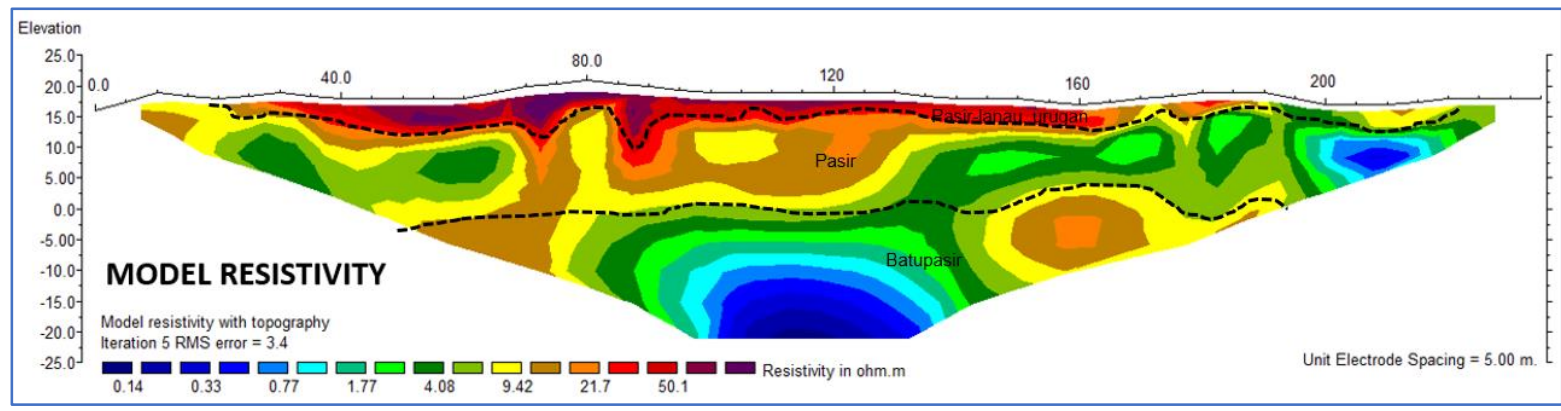

Gambar 6. Penampang 3 yang memperlihatkan kondisi bawah permukaan di rel sebelah barat Stasiun Ujungnegoro. Satuan paling atas berupa pasir, lanau dan urugan, satuan tengah berupa endapan pasir dan terbawah satuan batupasir yang nampak mulai terlihat mengandung airtanah.

Penampang geolistrik 3 (Gambar 6) terletak $750 \mathrm{~m}$ di sebelah timur Stasiun Ujungnegoro. Hasil analisis penampang menunjukkan bahwa kondisi bawah permukaan dari lintasan ini tersusun oleh 3 satuan batuan, yaitu paling atas berupa alluvial (pasir-lanau) dan urugan, dibagian tengah berupa endapan pasir dan yang paling bawah adalah batupasir. Satuan endapan teratas mempunyai ketebalan sampai $4 \mathrm{~m}$, satuan dibawahnya mempunyai ketebalan $15 \mathrm{~m}$ dan yang paling bawah dengan ketebalan lebih dari $20 \mathrm{~m}$. Lapisan tengah mempunyai ketebalan yang relatif sama dari ujung barat sampai ujung timur dan untuk lapisan terbawah nampak mulai terlihat adanya airtanah pada kedalaman >35 m. Melihat dari komposisi batuan/endapan di lintasan ini, secaara umum nampaknya tidak ada hal yang perlu dikuatirkan, hanya sedikit di ujung timur ada penebalan urugan pada lapisan teratas dan tepat dibawahnya tersusun oleh satuan lempung. Hal ini tidak akan menimbulkan masalah bila drainase berjalan dengan baik.

\subsection{Diskusi}

Salah satu peristiwa deformasi tanah yang sering merusak bangunan diatasnya adalah amblesan. Amblesan dapat disebabkan oleh berbagai faktor, diantaranya adalah pengambilan air bawah tanah, kompaksi, drainase tanah organik, penambangan bawah tanah dan pencairan permafrost (Miller, 2013). Selain itu, faktor kandungan lempung pada tanah juga akan memungkinkan swell-shrinkage behavior. Tekanan dari proses swelling (mengembang) dapat mengakibatan pengangkatan struktur, sementara shrinkage (penyusutan) dapat menimbulkan proses penurunan secara tidak merata (Mokhtari, 2012).
Kondisi tanah penopang rel di sekitar Stasiun Ujungnegoro beberapa kali mengalami amblesan. Untuk mengetahui penyebabnya dilakukan analisis faktor horizontal (permukaan) dan faktor vertikal (stratifikasi endapan/batuannya). Terkait dengan hal tersebut, untuk mengetahui faktor vertikalnya telah dilakukan pengukuran geolistrik dan penggalian informasi kondisi cekungan airtanah dari data sekunder peta cekungan air tanah, sedang untuk mengetahui faktor horizontalnya telah dilakukan pengamatan topografi lokal, jenis tanah/batuannya dan drainase di lapangan.

Hasil analisis dari semua data dan informasi yang ada dapat disimpulkan bahwa amblesan yang terjadi pada penampang 2 disebabkan oleh dua faktor penyebab, yaitu secara vertikal dijumpainya satuan lempung dibawah lokasi tempat terjadinya amblesan (Gambar 5.), sehingga memungkinkan berkembangnya swell and shrinkage behavior bila terjadi musim kemarau panjang yang dilanjutkan dengan musim penghujan dan secara horizontal, dimana urugan penopang rel bertindak sebagai bendung dari pusat aliran air pada dataran aluvial yang diapit oleh tinggian Formasi Damar. Dibawah area amblesan, permukaan batupasir membentuk lekukan (seperti kanal). Bentuk ini dapat disebabkan oleh 2 hal, pertama karena proses erosi sebelum endapan diatasnya terbentuk, atau karena proses pensesaran seperti yang tergambar pada penampang 2. Pada Gambar 7 dari sisi selatan sampai utara terdapat 4 lajur rel kereta. Kondisi amblesan yang paling nyata adalah pada rel sisi paling utara. Dengan fenomena ini menunjukkan bahwa bila sesar ada dan sesuai dengan yang diinterpretasikan pada Penampang 2 (Gambar 5) maka sesarnya bukan 
merupakan sesar aktif, dimana sesar berhenti sampai pada batupasir tidak memotong satuan lempung-pasir serta alluvial.

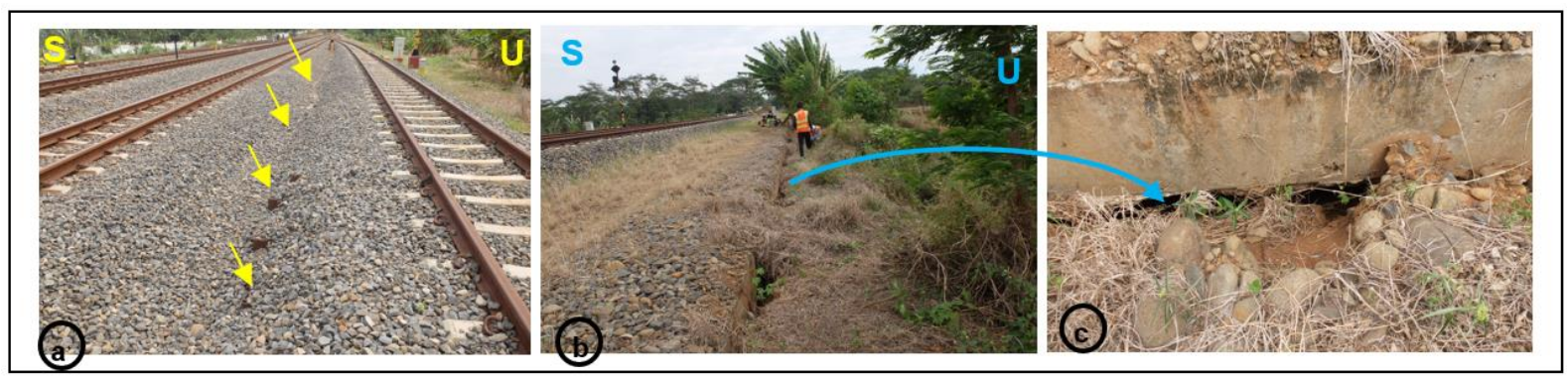

Gambar 7. a.Memperlihatkan cekungan pada balast tempat tambahan pasokan air hujan masuk (panah kuning), dan rel sebelah kanannya/paling utara sering ambles, b dan c memperlihatkan rongga akibat pengaruh gerusan air dan amblesan (Sumber Foto: Raditya)

Pengaruh sesar nampak tidak ikut berperan dalam peristiwa amblesan disini. Bila melihat morofologi cekung pada balast antar rel (hal yang umum) yang ditunjukkan dengan anak panah kuning (Gambar 7.a.), material bawah rel (Gambar 7.b. dan c), serta topografi lokal (Gambar 8.), faktor aliran air memegang peran penting dalam amblesan. Nampak bahwa rel berada seolah olah membendung pola aliran dari arah selatan (anak panah biru pada Gambar 8). Hal ini juga diperkuat dengan arah lepasan airtanah pada Peta Cekungan Airtanah Lembar Jawa Tengah-Yogyakarta (Setiadi, 2004) yang mengarah ke utara. Aliran air dari sisi selatan ke utara sedah disalurkan melalui culvert, akan tetapi karena badan rel seolah-olah membentuk bendungan sehingga culvert nampaknya kurang mampu mengalirkannya dengan baik. Sehingga ada genangan di bagian selatan rel dan sebagian meresap mengalir ke utara tidak melalui culvert. Hal ini ditambah dengan pasokan air di cekungan balast tadi. Dengan adanya aliran diluar culvert ini, menjadikan tanah penopang rel sisi utara mengalami pengikisan (Gambar 7.b. dan c) dan memungkinkan amblesan terjadi berulang-ulang.

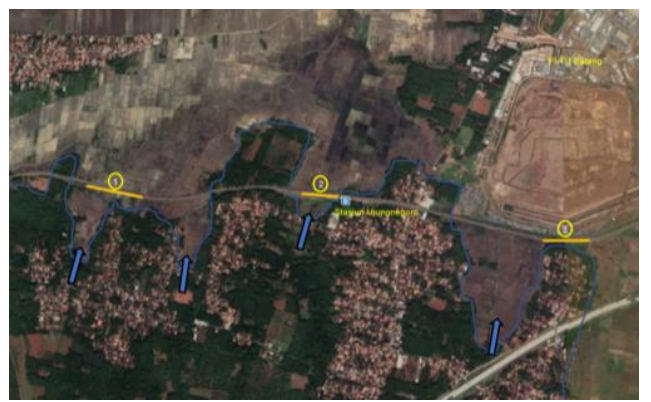

Gambar 8. Memperlihatkan batas Formasi Damar berupa garis biru). Formasi Damar mempunyai elevasi lebih tinggi dibandingkan dengan alluvial (berupa dataran).

\section{KESIMPULAN}

- Berdasarkan analisis hasil survei geolistrik menunjukkan bahwa komposisi tanah dibawah rel yang ambles mempunyai kandungan lempung yang memungkinkan terjadi swell and shrinkage behavior.

- Hal lain yang didapat dari analisis penampang geolistriknya adalah bahwa kondisi bawah permukaan tepat di bawah amblesan merupakan cekungan batupasir yang berada di bawah endapan pasir, lanau dan alluvial, sehingga bentuk ini menjadi "kanal" tempat konsentrasi aliran air bawah tanah.

- Faktor dominan yang menyebabkan terjadinya amblesan adalah karena posisi rel bertindak membendung aliran air dari arah selatan. Hal ini terlihat dari gerusan pada sisi utara tanah penopang rel Ujungnegoro.

\section{PERSANTUNAN}

Dalam kesempatan ini, penulis mengucapkan terimakasih kepada Mulyo Harris Pradono dan Raditya Panji Umbara yang telah bersama-sama melakukan pengamatan dan diskusi permasalahan jalur kereta api Jakarta-Surabaya, sehingga diskusi yang pernah dilakukan dapat menjadi tambahan informasi penulis dalam menyelesaikan tulisan ini. 


\section{DAFTAR PUSTAKA}

Condon, W.H, L.Pardyanto, K.B.Kedner, T.C.Amin dan H.Samodra, 1996, Peta Geologi Lembar Banjarnegara dan Pekalongan, Pusat Penelitian dan Pengembangan Geologi.

Damanik, C, 2018, Longsor di Cijeruk Bogor, Rel KA Sepanjang 40 Meter Menggantung

Ding, P., C. Jia, S. Di, J. Wu and R.Wei, 2021, Analysis and Evaluation of Land Subsidence along Linear Engineering Based on InSAR Data. KSCE J Civ Eng (2021). https://doi.org/10.1007/s12205021-0201-z

Huang, L., H. Xiao, S. Yang, and Y. Han, 2015, Effects of Groundwater Exploitation on Embankment for High-speed Railway Lines, The Open Civil Engineering Journal, 2015, 9, 417-422

Huang R.Q., L.Y.Rong, Q. Ke, W. Ke, 2013, Engineering Geological Assessment for Route Selection of Railway Line in Geologically Active Area: A Case Study in China, J. Mt. Sci. (2013) 10(4): 495-508. DOI: 10.1007/s11629-013-2660-2

Kuvaini, A. 2008, Kajian Penentuan rute Kereta Api Berwawasan ILingkungan Sebagai Alat Transportasi Batubara di Propinsi Kalimantan Selatan, Sekolah Pasca Sarjana, Institut Pertanian Bogor.

Linlin Ge, Xiaojing Li, Hsing-chung Chang, Alex Hayman Ng, Kui Zhang \& Zhe $\mathrm{Hu}$ (2010) Impact of ground subsidence on the Beijing-Tianjin high-speed railway as mapped by radar interferometry, Annals of GIS, 16:2, 91-

102, DOI: $10.1080 / 19475683.2010 .4$ 92125

Marisa, 2005, Studi Manajemen Dan Biaya Pemeliharaan Serta Peningkatan Rel Kereta Api, Fakultas Teknik Sipil, Universitas Kristen Maranatha, Bandung.

Miller, K.L., 2013, Causes of Land Subsidence, https://www.cga.ct.gov/2013/rpt/20 13-R-0277.htm

Mokhtari, M and B. abbas, 2012, Swell-Shrink Behavior of Expansive Soils, Damage and Control, Department of civil engineering, University of Hormozgan, Iran, EJGE, Vol. 17, 2673-2682 pp.
Setiadi, H. (2004). Peta Cekungan Air tanah Provinsi Jawa Tengah dan Daerah Istimewa Yogyakarta. Direktorat Tata Lingkungan Geologi dan Kawasan Pertambangan, Bandung

Toyudho, E.S., 2012, Perbaikan Rel Kereta Cilebut Perlu 24 Hari, https://metro.tempo.co/read/443460/ perbaikan-rel-kereta-cilebut-perlu-24hari/full\&view=ok

Ye, C., Y. Yang, F. Tian, Y. Luo and Y. Zhou, 2015, Numerical analysis to determine the impact of land subsidence on high-speed railway routes in Beijing, China, Proceedings of the International Association of Hydrological Sciences 372:493-497, DOI:10.5194/piahs-372-493-2015

Yunibar, 2019, Ratusan Penumpang KA di Stasiun Tegal Terlantar akibat Banjir Batang

Ziyi Yang, 2015, Monitoring and Predicting Railway Subsidence Using InSAR and Time Series Prediction Techniques, Doctoral Dissertation, School of Civil Engineering College of Engineering and Physical Sciences, The University of Birmingham, UK.

https://jateng.inews.id/berita/ratusanpenumpang-ka-di-stasiun-tegalterlantar-akibat-banjir-batang

https://regional.kompas.com/read/2018/02/0 5/18320001/longsor-di-cijerukbogor-rel-ka-sepanjang-40-metermenggantung 